\title{
GMR
}

\section{Phenotypic and biochemical profile changes in calendula (Calendula officinalis L.) plants treated with two chemical mutagenesis}

\author{
Y.I. El-Nashar ${ }^{1,2}$ and A.A. Asrar ${ }^{1}$ \\ ${ }^{1}$ Plant Production Department, College of Food \& Agricultural Sciences, \\ King Saud University, Saudi Arabia \\ ${ }^{2}$ Ornamental Plants and Landscape Gardening Research Department, \\ Horticultural Research Institute, Agricultural Research Center, Giza, Egypt \\ Corresponding author: Y.I. El-Nashar \\ E-mail: yelnashar@ksu.edu.sa \\ Genet. Mol. Res. 15 (2): gmr.15028071 \\ Received November 17, 2015 \\ Accepted January 18, 2016 \\ Published May 6, 2016 \\ DOI http://dx.doi.org/10.4238/gmr.15028071
}

\begin{abstract}
Chemical mutagenesis is an efficient tool used in mutationbreeding programs to improve the vital characters of the floricultural crops. This study aimed to estimate the effects of different concentrations of two chemical mutagens; sodium azide (SA) and diethyl sulfate (DES). The vegetative growth and flowering characteristics in two generations $\left(M_{1}\right.$ and $\left.M_{2}\right)$ of calendula plants were investigated. Seeds were treated with five different concentrations of SA and DES (at the same rates) of $1000,2000,3000,4000$, and $5000 \mathrm{ppm}$, in addition to a control treatment of $0 \mathrm{ppm}$. Results showed that lower concentrations of SA mutagen had significant effects on seed germination percentage, plant height, leaf area, plant fresh weight, flowering date, inflorescence diameter, and gas-exchange measurements in plants of both generations. Calendula plants tended to flower earlier under low mutagen concentrations (1000 ppm), whereas higher concentrations delayed flowering significantly. Positive results on seed germination, plant height, number of branches, plant fresh weight, and leaf area were observed in the $\mathrm{M}_{2}$-generation at
\end{abstract}


lower concentrations of SA (1000 ppm), as well as at $4000 \mathrm{ppm}$ DES on number of leaves and inflorescences. The highest total soluble protein was detected at the concentrations of $1000 \mathrm{ppm}$ SA and $2000 \mathrm{ppm}$ DES. DES showed higher average of acid phosphatase activity than SA. Results indicated that lower concentrations of SA and DES mutagens had positive effects on seed germination percentage, plant height, leaf area, plant fresh weight, flowering date, inflorescence diameter, and gasexchange measurements. Thus, lower mutagen concentrations could be recommended for better floral and physio-chemical performance.

Key words: Diethyl sulfate; Enzyme activity; Gas-exchange; Mutation; Sodium azide

\section{INTRODUCTION}

Calendula officinalis $\mathrm{L}$. is an annual herb belonging to the family Asteraceae, native to the Mediterranean region. It is cultivated for ornamental and medicinal purposes in Europe and Americas. In the last decade, there were more than 2543 mutant cultivars derived from 175 plant species including ornamentals, cereals, oilseeds, pulses, vegetables, fruits, and fibers released in 50 countries worldwide (Chopra, 2005). Chemical mutagenesis is a simple approach used to create mutation in economically valuable plants, for improvement of their agronomic parameters. In any mutation-breeding program, selection of an effective and efficient mutagen is essential to produce a high frequency of desirable mutations (Roychowdhury and Tah, 2011).

Many chemical mutagens have been employed to obtain useful mutants in various crop species (Singh and Singh, 2001). Several studies have emphasized that artificial induction of mutations by sodium azide (SA) and diethyl sulfate (DES) provides a tool to overcome the limitations in variability in floricultural plants, especially carnations. These chemicals induce growth abnormalities, due to their effects on cell death and suppression of mitosis (Mensah and Obadoni, 2007; Roychowdhury and Tah, 2011). SA and DES are responsible for creating point DNA mutations that induce genetic variability. Thus, they are considered important tools to enhance agronomic traits in several economic plant species (Tah, 2006). The role of mutation breeding in increasing the genetic variability for desired agronomic traits in various plant species has been demonstrated in a number of studies (e.g., Mostafa, 2011; Roychowdhury et al., 2012).

The mutagen dose is a prime consideration in any mutagenesis program. Generally, higher concentrations of the mutagen lead to greater biological damage in the form of reduced seed germination, seedling injury, pollen sterility, and reduced survival at maturity, which could be considered an indication of the mutagenic effects (Gaul, 1964). To reduce the negative effects on plant parameters, more knowledge about the influence of exposure time and mutagen concentrations are required (Khan et al., 2009).

It is important to induce genetic variability by means of mutagens such as SA and DES in plant mutation programs (Hussein et al., 1974; Abd El-Maksoud and El-Mahrouk, 1992; El-Nashar, 2006). For comparative studies of crops and their wild relatives in plant germplasm collections, a complementary approach using isozymes could be more appropriate to generate accurate estimations of genetic diversity and relationships comparing to alternative methods.

This study was carried out to investigate the dose effect of SA and DES mutagens on 
vegetative growth, flowering, yield parameters, and gas-exchange across the two generations $\left(\mathrm{M}_{1}\right.$ and $\left.\mathrm{M}_{2}\right)$ of $C$. officinalis $\mathrm{L}$. The mutagen effects on induction of total soluble protein, enzymatic activities of acid phosphatase, and catalase were also assessed.

\section{MATERIAL AND METHODS}

This study was carried out at the Department of Plant Production, College of Food and Agricultural Sciences, King Saud University, for two seasons (2012/2013 and 2013/2014) under greenhouse conditions.

\section{Plant materials}

Calendula seeds (C. officinalis L. cv. calypso yellow) provided by Sakata's Reliable Seeds (Morgan Hill, CA, USA), were treated with six different concentrations $(0,1000,2000$, 3000,4000 , and $5000 \mathrm{ppm}$ ) of SA and DES. The $\mathrm{M}_{1}$-generation was run in the first season on November 7, 2012, whereas the $\mathrm{M}_{2}$-generation was done in the second season on October 1, 2013. Plants were planted in $15-\mathrm{cm}$ pots, one plant per pot. Twenty percent of the $M_{1}$-plants, which survived in each treatment, were selected and selfed, in order to obtain the $M_{2}$ seeds according to Sinhamahapatra and Rakshit (1990).

\section{Experimental design}

The experimental procedure used was a split plot design, with three replicates for each of the $\mathrm{M}_{1}-$ and $\mathrm{M}_{2}$-generations (Steel and Torrie, 1980). In the first season, each replicate contained 12 treatments [the two chemical mutagens (SA and DES) applied at six different concentrations each]. The main plots were devoted to the two chemical mutagens and the subplots included the concentrations. Fifty seeds were used for each treatment in each replicate; the total number of seeds used in the experiment was 1800 seeds/season.

\section{Experimental data}

The percentage of seed germination was recorded after 6 weeks from sowing. The calendula plants were grown until flower maturity when the plants were harvested. At the harvesting stage, the plant height and flower diameter were measured. The number of leaves per plant was counted, and leaf area was measured using a leaf area meter (LI-COR, Lincoln, NE, USA). The number of branches and flowers per plant were also calculated. The flowering date (days from sowing) in each treatment was determined, and the fresh shoot and dry weights were recorded. The shoot dry weight was determined by drying the shoots in an oven at $70^{\circ} \mathrm{C}$ for $48 \mathrm{~h}$ until the weight was constant. These data were collected for both $\mathrm{M}_{1}$ - and $\mathrm{M}_{2}$-generations in two successive experimental seasons.

\section{Physiological parameters}

The net leaf photosynthetic rate, stomatal conductance, transpiration rate, and intercellular $\mathrm{CO}_{2}$ concentration were determined between 8:00 to 9:30 am at the harvesting stage from fully expanded third top leaf. This was done using a portable open flow gas- 
exchange system LI-6400 (LI-COR) at a light-saturating intensity on a sunny day when the photosynthetically active radiation was $640 \mu \mathrm{mol} \cdot \mathrm{m}^{-2} \cdot \mathrm{s}^{-1}$, the air temperature was $29^{\circ} \mathrm{C}$, and the relative humidity was $26 \%$ on a fully expanded top leaf of the main axis of the plant. The recorded measurements were average of four readings per plot.

Eight-week-old seedlings were used to extract chlorophyll (Chl). About 0.025 to $0.035 \mathrm{~g}$ of leaflets were used to extract Chl using $N, N$-dimethylformamide (DMF) by grinding the leaflets with $2 \mathrm{~mL}$ DMF solvent using in a mortar with a pestle. The homogenate was centrifuged at $2500 \mathrm{rpm}$ in a bench centrifuge for $10 \mathrm{~min}$. The pellet was then extracted and combined with $1 \mathrm{~mL}$ solvent in a homogenizer and the pooled supernatants were adjusted to a final volume of $8 \mathrm{~mL}$. The spectrum was recorded between 750 and $600 \mathrm{~nm}$ and the main red absorption peak was automatically determined by the Amersham Pharmacia Biotech, Ultrospec 2000, UV/visible spectrophotometer (Cambridge, England). Chl $a, b$, and total $\mathrm{Chl}(a+b)$ concentrations in $\mu \mathrm{M}$ were then calculated using the equations as described by Porra et al. (1989):

$$
\begin{array}{cc}
\text { Chl } a=13.43 A^{663.8}-3.47 A^{646.8} & \text { (Equation 1) } \\
\text { Chl } b=22.90 A^{663.8}-5.38 A^{646.8} & \text { (Equation 2) } \\
\text { Chl } a+b=19.43 A^{663.8}-8.05 A^{646.8} & \text { (Equation 3) }
\end{array}
$$

Note that $A^{646.8}$ and $A^{663.8}$ refer to absorbance at 663.8 and $646.8 \mathrm{~nm}$ wavelengths, respectively. The unit of the pigment concentration is nanomoles per milliliter.

\section{Total soluble protein content}

The total protein content was determined following Lowry et al. (1951). Calendula seedlings $(0.5 \mathrm{mg})$ were ground in $25 \mathrm{~mL}$ Tris- $\mathrm{HCl}$ buffer, $\mathrm{pH}$ 7.6. The mixture was centrifuged at $9000 \mathrm{~g}$ under freezing for $5 \mathrm{~min}$ at $4^{\circ} \mathrm{C}$. The supernatant was then transferred to a new vial and kept under a frozen temperature of $-20^{\circ} \mathrm{C}$ until further analysis. The total soluble protein concentrations were then determined using a spectrophotometry $(750 \mathrm{~nm})$.

\section{Enzymatic activities}

Acid phosphatase enzyme activity was assayed in the crude extract of 2-weekold calendula seedlings as reported by dos Prazeres et al. (2004). Catalase activity was determined as previously described (Cakmak et al., 1993). Briefly, the reaction solution $(3 \mathrm{~mL})$ for the catalase enzyme was comprised of $50 \mathrm{mM}$ phosphate buffer, $\mathrm{pH} 7.0,15$ $\mathrm{mM} \mathrm{H} \mathrm{O}_{2}$, and $50 \mu \mathrm{L}$ enzyme extracts. The reaction was initiated by adding $\mathrm{H}_{2} \mathrm{O}_{2}$ to the reaction solution. The catalase activity was determined by tracing the decomposition of $\mathrm{H}_{2} \mathrm{O}_{2}$ and measuring the absorbance decrease at $240 \mathrm{~nm}$ for $1 \mathrm{~min}$. The catalase activity was expressed as amount of enzyme that breaks down $1 \mu \mathrm{mol} \mathrm{H}_{2} \mathrm{O}_{2} \cdot{ }^{-1} \mathrm{mg} \cdot \mathrm{min}^{-1}$ under the assayed described conditions. 


\section{RESULTS}

\section{Seed germination}

The mean values for the influences of the two chemical mutagens on seed germination percentage were found to be significant in the $M_{1}$-generation with stronger effects of DES than SA. The effects of the different concentrations of both mutagens on the seed germination trait were significant in both generations (Table 1). There was a clear decrease in seed germination percentage by increasing the mutagen concentration starting from $1000\left(55.17 \%\right.$ for $\mathrm{M}_{1}$ and $67.16 \%$ for $\left.\mathrm{M}_{2}\right)$ to $5000 \mathrm{ppm}\left(33.17 \%\right.$ for $\mathrm{M}_{1}$ and $31.03 \%$ for $\left.\mathrm{M}_{2}\right)$, as compared with the control treatment (56.33 and $63.17 \%$ for $\mathrm{M}_{1}$ and $\mathrm{M}_{2}$, respectively).

Table 1. Mean performance of the vegetative parameters of Calendula officinalis L. plants as affected by two different chemical mutagens; mutagen: concentrations and their interactions in $\mathrm{M}_{1}$ - and $\mathrm{M}_{2}$-generations during the years of 2013 and 2014 .

\begin{tabular}{|c|c|c|c|c|c|c|c|c|c|c|}
\hline \multirow{2}{*}{$\begin{array}{l}\text { Treatments } \\
\text { Chemical mutagens }\end{array}$} & \multicolumn{2}{|c|}{ Germination percentage (\%) } & \multicolumn{2}{|c|}{ Plant height $(\mathrm{cm})$} & \multicolumn{2}{|c|}{$\begin{array}{l}\text { Number of branches per } \\
\text { plant }\end{array}$} & \multicolumn{2}{|c|}{ No. of leaves per plant } & \multicolumn{2}{|c|}{ Leaf area $\left(\mathrm{cm}^{2}\right)$} \\
\hline & $\mathrm{M}_{1}$ & $\mathrm{M}_{2}$ & $\mathrm{M}_{1}$ & $\mathrm{M}_{2}$ & $\mathrm{M}_{1}$ & $\mathrm{M}_{2}$ & $\mathrm{M}_{1}$ & $\mathrm{M}_{2}$ & $\mathrm{M}_{1}$ & $\mathrm{M}_{2}$ \\
\hline SA & $41.67^{b}$ & $52.67^{\mathrm{a}}$ & $13.59^{\mathrm{a}}$ & $16.44^{\mathrm{a}}$ & $5.87^{\mathrm{a}}$ & $4.09^{\mathrm{a}}$ & $24.11^{\mathrm{a}}$ & $21.56^{\mathrm{b}}$ & $152.17^{\mathrm{b}}$ & $238.94^{\mathrm{a}}$ \\
\hline DES & $52.22^{\mathrm{a}}$ & $50.94^{\mathrm{a}}$ & $12.49^{\mathrm{a}}$ & $15.05^{\mathrm{a}}$ & $7.08^{\mathrm{a}}$ & $4.42^{\mathrm{a}}$ & $23.57^{\mathrm{a}}$ & $28.39^{\mathrm{a}}$ & $182.45^{\mathrm{a}}$ & $210.55^{\mathrm{b}}$ \\
\hline \multicolumn{11}{|l|}{ Concentrations } \\
\hline Control & $56.33^{\mathrm{a}}$ & $63.17^{\mathrm{b}}$ & $14.64^{\mathrm{a}}$ & $13.45^{\mathrm{b}}$ & $6.25^{\mathrm{a}}$ & $3.34^{\mathrm{b}}$ & $27.68^{\mathrm{a}}$ & $25.51^{\mathrm{a}}$ & $198.35^{\mathrm{a}}$ & $208.13^{\mathrm{b}}$ \\
\hline $1000 \mathrm{ppm}$ & $55.17^{\mathrm{a}}$ & $67.16^{\mathrm{a}}$ & $15.69^{\mathrm{a}}$ & $18.90^{\mathrm{a}}$ & $6.45^{\mathrm{a}}$ & $5.58^{\mathrm{a}}$ & $28.37^{\mathrm{a}}$ & $27.05^{\mathrm{a}}$ & $159.35^{\mathrm{b}}$ & $262.81^{\mathrm{a}}$ \\
\hline $2000 \mathrm{ppm}$ & $50.67^{\mathrm{ab}}$ & $57.05^{\mathrm{c}}$ & $10.83^{\mathrm{c}}$ & $12.34^{\mathrm{b}}$ & $7.17^{\mathrm{a}}$ & $4.07^{\mathrm{ab}}$ & $22.67^{b}$ & $26.93^{\mathrm{a}}$ & $175.66^{\mathrm{ab}}$ & $244.62^{\mathrm{ab}}$ \\
\hline $3000 \mathrm{ppm}$ & $43.17^{b}$ & $52.51^{\mathrm{d}}$ & $13.96^{\mathrm{ab}}$ & $18.33^{\mathrm{a}}$ & $6.61^{\mathrm{a}}$ & $4.40^{\mathrm{ab}}$ & $20.13^{\mathrm{b}}$ & $25.18^{\mathrm{a}}$ & $201.39^{\mathrm{a}}$ & $250.54^{\mathrm{ab}}$ \\
\hline $4000 \mathrm{ppm}$ & $43.16^{\mathrm{b}}$ & $40.12^{\mathrm{e}}$ & $11.75^{\text {bc }}$ & $19.22^{\mathrm{a}}$ & $6.25^{\mathrm{a}}$ & $5.03^{\mathrm{a}}$ & $25.63^{\mathrm{a}}$ & $24.98^{\mathrm{a}}$ & $156.51^{\mathrm{bc}}$ & $211.02^{\mathrm{b}}$ \\
\hline $5000 \mathrm{ppm}$ & $33.17^{\mathrm{c}}$ & $31.03^{f}$ & $11.40^{\mathrm{c}}$ & $12.19^{\mathrm{b}}$ & $6.13^{\mathrm{a}}$ & $3.19^{\mathrm{b}}$ & $18.58^{\mathrm{b}}$ & $20.28^{\mathrm{a}}$ & $112.55^{\mathrm{c}}$ & $174.31^{\mathrm{c}}$ \\
\hline \multicolumn{11}{|l|}{ Interactions } \\
\hline Control & $58.00^{\mathrm{ab}}$ & $63.33^{\mathrm{bc}}$ & $16.00^{\mathrm{ab}}$ & $11.86^{\mathrm{fg}}$ & $5.32^{\mathrm{a}}$ & $3.01^{\mathrm{b}}$ & $28.87^{\mathrm{a}}$ & $24.01^{\mathrm{ab}}$ & $190.04^{\mathrm{abc}}$ & $202.20^{\mathrm{b}}$ \\
\hline $\mathrm{SA}+1000 \mathrm{ppm}$ & $46.67^{\mathrm{b}-\mathrm{e}}$ & $69.05^{\mathrm{a}}$ & $16.43^{\mathrm{a}}$ & $24.47^{\mathrm{a}}$ & $5.80^{\mathrm{a}}$ & $6.34^{\mathrm{a}}$ & $28.53^{\mathrm{ab}}$ & $26.02^{\mathrm{ab}}$ & $185.30^{\mathrm{abc}}$ & $289.48^{\mathrm{a}}$ \\
\hline $\mathrm{SA}+2000 \mathrm{ppm}$ & $39.34^{\text {cde }}$ & $52.31^{\mathrm{d}}$ & $11.72^{\mathrm{def}}$ & $15.10^{\mathrm{c}-\mathrm{f}}$ & $6.71^{\mathrm{a}}$ & $4.02^{\mathrm{b}}$ & $23.83^{\mathrm{a}-\mathrm{d}}$ & $24.33^{\mathrm{ab}}$ & $183.39^{\mathrm{abc}}$ & $279.79^{\mathrm{ab}}$ \\
\hline $\mathrm{SA}+3000 \mathrm{ppm}$ & $37.66^{\mathrm{de}}$ & $63.30^{\mathrm{bc}}$ & $15.58^{\mathrm{abc}}$ & $17.61^{\mathrm{bcd}}$ & $6.77^{\mathrm{a}}$ & $4.13^{\mathrm{b}}$ & $23.04^{\mathrm{a}-\mathrm{d}}$ & $21.33^{\mathrm{ab}}$ & $183.05^{\mathrm{abc}}$ & $264.48^{\mathrm{ab}}$ \\
\hline $\mathrm{SA}+4000 \mathrm{ppm}$ & $37.00^{\mathrm{de}}$ & $36.30^{\mathrm{f}}$ & $9.78^{\mathrm{f}}$ & $16.74^{\text {cde }}$ & $5.13^{\mathrm{a}}$ & $4.00^{\mathrm{b}}$ & $21.10^{\mathrm{a}-\mathrm{d}}$ & $20.29^{\mathrm{bc}}$ & $91.55^{\text {cd }}$ & $203.83^{\mathrm{ab}}$ \\
\hline $\mathrm{SA}+5000 \mathrm{ppm}$ & $31.43^{\mathrm{e}}$ & $31.67^{\mathrm{g}}$ & $12.05^{\mathrm{c}-\mathrm{f}}$ & $12.78^{\mathrm{efg}}$ & $5.52^{\mathrm{a}}$ & $3.06^{\mathrm{b}}$ & $19.33^{\text {bcd }}$ & $13.35^{\mathrm{c}}$ & $79.68^{\mathrm{d}}$ & $193.87^{\mathrm{b}}$ \\
\hline Control & $54.66^{\mathrm{abc}}$ & $63.21^{\mathrm{bc}}$ & $13.28^{\mathrm{a}-\mathrm{f}}$ & $15.03^{\mathrm{c}-\mathrm{f}}$ & $7.17^{\mathrm{a}}$ & $3.67^{\mathrm{b}}$ & $26.50^{\mathrm{abc}}$ & $27.11^{\mathrm{ab}}$ & $206.76^{\mathrm{ab}}$ & $214.07^{\mathrm{ab}}$ \\
\hline DES+1000 ppm & $63.67^{\mathrm{a}}$ & $65.33^{b}$ & $14.95^{\mathrm{a}-\mathrm{d}}$ & $13.34^{\mathrm{d}-\mathrm{g}}$ & $7.11^{\mathrm{a}}$ & $4.83^{\mathrm{ab}}$ & $28.21^{\mathrm{ab}}$ & $28.08^{\mathrm{ab}}$ & $133.41^{\mathrm{bcd}}$ & $236.14^{\mathrm{ab}}$ \\
\hline $\mathrm{DES}+2000 \mathrm{ppm}$ & $62.00^{\mathrm{ab}}$ & $61.66^{c}$ & $9.95^{\text {ef }}$ & $9.58^{\mathrm{g}}$ & $7.63^{\mathrm{a}}$ & $4.12^{\mathrm{b}}$ & $21.52^{\mathrm{a}-\mathrm{d}}$ & $29.53^{\mathrm{a}}$ & $167.93^{\mathrm{a}-\mathrm{d}}$ & $209.45^{\mathrm{b}}$ \\
\hline $\mathrm{DES}+3000 \mathrm{ppm}$ & $48.67^{\mathrm{a}-\mathrm{d}}$ & $41.67^{\mathrm{e}}$ & $12.33^{b-f}$ & $19.04^{\mathrm{bc}}$ & $6.47^{\mathrm{a}}$ & $4.67^{\mathrm{ab}}$ & $17.23^{\mathrm{d}}$ & $29.04^{\mathrm{ab}}$ & $219.73^{\mathrm{a}}$ & $236.61^{\mathrm{ab}}$ \\
\hline $\mathrm{DES}+4000 \mathrm{ppm}$ & $49.33^{\mathrm{a}-\mathrm{d}}$ & $43.64^{\mathrm{e}}$ & $13.72^{\mathrm{a}-\mathrm{e}}$ & $21.70^{\mathrm{ab}}$ & $7.37^{\mathrm{a}}$ & $6.06^{\mathrm{a}}$ & $30.17^{\mathrm{a}}$ & $29.67^{a}$ & $221.46^{\mathrm{a}}$ & $212.33^{\mathrm{b}}$ \\
\hline $\mathrm{DES}+5000 \mathrm{ppm}$ & $35.09^{\mathrm{de}}$ & $30.33^{\mathrm{g}}$ & $10.75^{\text {ef }}$ & $11.61 \mathrm{f}^{\mathrm{g}}$ & $6.77^{\mathrm{a}}$ & $3.32^{\mathrm{b}}$ & $17.83^{\text {cd }}$ & $27.21^{\mathrm{ab}}$ & $145.43^{\mathrm{bc}}$ & $154.75^{\mathrm{c}}$ \\
\hline
\end{tabular}

Values in each column followed by different superscript letter(s) are significantly different at $\mathrm{P} \leq 0.05 . \mathrm{SA}=$ sodium azide; DES = diethyl sulfate.

The interactions between the two chemical mutagens and their concentrations on seed germination were significant in both generations. The germination percentage increased with DES at $1000 \mathrm{ppm}$ in the $\mathrm{M}_{1}$-generation, whereas it increased with SA at $1000 \mathrm{ppm}$ only in the $M_{2}$-generation. In the $M_{1}$ - and $M_{2}$-generations, the lowest percentage of seed germination was recorded for SA at $5000 \mathrm{ppm}$ in the $\mathrm{M}_{1}$-generation, and for both SA and DES at $5000 \mathrm{ppm}$ ( 31.43 and $30.33 \%$, respectively) in the $\mathrm{M}_{2}$-generation (Table 1 ).

\section{Vegetative parameters}

There were no significant differences between the chemical mutagens on plant height in the $\mathrm{M}_{1}$ - and $\mathrm{M}_{2}$-generations. However, there were significant differences among the six 
concentrations, as well as among the interactions between the two chemical mutagens and their concentrations in both generations (Table 1). The treatments with concentrations of 2000 and $5000 \mathrm{ppm}$ had the smallest average plant height $\left(10.83 \mathrm{~cm}\right.$ for $\mathrm{M}_{1}$ and $12.19 \mathrm{~cm}$ for $\left.\mathrm{M}_{2}\right)$, whereas the greatest plant heights were detected at the concentrations of $1000 \mathrm{ppm}(15.69 \mathrm{~cm}$ for $\left.\mathrm{M}_{1}\right)$ and $4000 \mathrm{ppm}\left(19.22 \mathrm{~cm}\right.$ for $\left.\mathrm{M}_{2}\right)$. The maximum average plant height was produced under SA at $1000 \mathrm{ppm}$ treatment (16.43 and $24.47 \mathrm{~cm}$ for the $\mathrm{M}_{1}-$ and $\mathrm{M}_{2}$-generations, respectively). The minimum average plant height was observed under SA at $4000 \mathrm{ppm}(9.78$ $\mathrm{cm}$ for $\left.\mathrm{M}_{1}\right)$ and under DES at $2000 \mathrm{ppm}\left(9.58 \mathrm{~cm}\right.$ for $\left.\mathrm{M}_{2}\right)$.

The mean values for the chemical mutagens, mutagen concentrations, and their interactions had no significant effects on branch number in the $\mathrm{M}_{1}$-generation; but the mutagen concentration and their interaction effects were significant for branch number in the $\mathrm{M}_{2}$ generation (Table 1). The greatest number of branches per plant was observed at $1000 \mathrm{ppm}$ for SA (6.34 for $\mathrm{M}_{2}$ ), while the smallest number was recorded for the SA control (3.01 for $\left.\mathrm{M}_{2}\right)$.

The mean number of leaves per plant was not significantly affected by the mutagen in the $\mathrm{M}_{1}$-generation, while this effect was significant in the $\mathrm{M}_{2}$-generation. The different concentrations had significant effects on this trait only in the $\mathrm{M}_{1}$-generation where the highest number of leaves per plant (28.37) was detected at $1000 \mathrm{ppm}$ and the lowest number of leaves (18.58) was recorded at $5000 \mathrm{ppm}$ (Table 1). The interactions between the mutagens and mutagen concentration showed no significant effects, neither in the $M_{1}-$ nor in the $M_{2}$ generation. In both generations, there was a trend towards a reduction in the number of leaves per plant as mutagen concentration increased; especially, in comparison with the highest concentration (5000 ppm) of SA in the $\mathrm{M}_{2}$-generation. The highest number of leaves was found with DES at $4000 \mathrm{ppm}$ (30.17 and 29.67) in the $\mathrm{M}_{1}$ - and $\mathrm{M}_{2}$-generations.

The chemical mutagens, mutagen concentration, and the interactions between the two factors had significant effects on leaf area of plants in both generations. The highest mutagen concentration of $5000 \mathrm{ppm}$ generated the lowest leaf area $\left(112.55\right.$ and $174.31 \mathrm{~cm}^{2}$ in the $\mathrm{M}_{1}$ and $\mathrm{M}_{2}$-generations, respectively). The largest leaf area was detected at concentrations of 3000 $\operatorname{ppm}\left(201.39 \mathrm{~cm}^{2}\right)$ for the $\mathrm{M}_{1}$-generation and at $1000 \mathrm{ppm}\left(262.81 \mathrm{~cm}^{2}\right)$ for the $\mathrm{M}_{2}$-generation. Regarding the interaction effect, the smallest leaf areas were detected at $5000 \mathrm{ppm}$ for the SA treatment $\left(79.68 \mathrm{~cm}^{2}\right)$ in the $\mathrm{M}_{1}$-generation and at $5000 \mathrm{ppm}$ DES $\left(154.75 \mathrm{~cm}^{2}\right)$ in the $\mathrm{M}_{2}$ generation. On the other hand, the largest leaf areas were found at the concentrations of $4000 \mathrm{ppm}$ DES $\left(221.46 \mathrm{~cm}^{2}\right)$ and $1000 \mathrm{ppm} \mathrm{SA}\left(289.48 \mathrm{~cm}^{2}\right)$ for the $\mathrm{M}_{1}$ - and $\mathrm{M}_{2}$-generations, respectively.

The mean values of the chemical mutagens, mutagen concentration, and their interactions did not show any significant differences in plant fresh weight during the $\mathrm{M}_{1}$ generation, whereas some differences were detected in the $\mathrm{M}_{2}$-generation (Table 2). The effects of the highest mutagen concentration $(5000 \mathrm{ppm})$ on plant fresh weight $(10.64 \mathrm{~g})$, seemed to be significantly more harmful in the $\mathrm{M}_{1}$-generation, comparing with the control (15.48 g). The plant fresh weight was higher in SA than in DES. There was a reduction trend in plant fresh weight as chemical concentrations increased from 1000 to $5000 \mathrm{ppm}$. The greatest plant fresh weight was observed at $1000 \mathrm{ppm}\left(16.79 \mathrm{~g}\right.$ for $\left.\mathrm{M}_{2}\right)$.

Regarding the interaction effect in the $\mathrm{M}_{2}$-generation, the highest plant fresh weight was recorded at $1000 \mathrm{ppm} \mathrm{SA} \mathrm{(21.98} \mathrm{g),} \mathrm{whereas} \mathrm{the} \mathrm{lowest} \mathrm{plant} \mathrm{fresh} \mathrm{weight} \mathrm{(7.37} \mathrm{g)} \mathrm{was}$ detected at the highest concentration of 5000 ppm DES.

In the $\mathrm{M}_{1}$-generation plants, only the chemical mutagen used had significant effects on plant dry weight. In contrast, mutagen concentration and its interaction with the chemical mutagen had no significant effects on plant dry weight (Table 2). 
Table 2. Mean performance of the flower parameters of Calendula officinalis L. plants as affected by two different chemical mutagens: mutagen concentrations and their interactions in $\mathrm{M}_{1}$ - and $\mathrm{M}_{2}$-generations during the years of 2013 and 2014.

\begin{tabular}{|c|c|c|c|c|c|c|c|c|c|c|}
\hline \multirow{3}{*}{$\begin{array}{l}\text { Treatments } \\
\text { Chemical mutagens }\end{array}$} & \multicolumn{2}{|c|}{$\begin{array}{l}\text { Plant fresh } \\
\text { weight }(\mathrm{g})\end{array}$} & \multicolumn{2}{|c|}{$\begin{array}{c}\text { Plant dry } \\
\text { weight }(\mathrm{g})\end{array}$} & \multicolumn{2}{|c|}{$\begin{array}{l}\text { Flowering } \\
\text { Date (day) }\end{array}$} & \multicolumn{2}{|c|}{$\begin{array}{c}\text { Number of } \\
\text { inflorescences per plant }\end{array}$} & \multicolumn{2}{|c|}{$\begin{array}{l}\text { Inflorescence } \\
\text { diameter }(\mathrm{cm})\end{array}$} \\
\hline & $\mathrm{M}_{1}$ & $\mathrm{M}_{2}$ & $\mathrm{M}_{1}$ & $\mathrm{M}_{2}$ & $\mathrm{M}_{1}$ & $\mathrm{M}_{2}$ & $\mathrm{M}_{1}$ & $\mathrm{M}_{2}$ & $\mathrm{M}_{1}$ & $\mathrm{M}_{2}$ \\
\hline & $12.93^{\mathrm{a}}$ & $16.50^{\mathrm{a}}$ & $2.65^{\mathrm{b}}$ & $3.82^{\mathrm{a}}$ & $141.87^{\mathrm{a}}$ & $184.88^{\mathrm{a}}$ & $8.42^{\mathrm{a}}$ & $6.89^{\mathrm{b}}$ & $3.75^{\mathrm{a}}$ & $3.96^{\mathrm{b}}$ \\
\hline$\overline{\mathrm{DES}}$ & $12.78^{\mathrm{a}}$ & $12.28^{\mathrm{b}}$ & $3.52^{\mathrm{a}}$ & $3.37^{\mathrm{a}}$ & $136.93^{\mathrm{b}}$ & $178.53^{\mathrm{b}}$ & $9.41^{\mathrm{a}}$ & $7.78^{\mathrm{a}}$ & $3.21^{\mathrm{a}}$ & $4.45^{\mathrm{a}}$ \\
\hline \multicolumn{11}{|l|}{ Concentrations } \\
\hline Control & $15.48^{\mathrm{a}}$ & $13.73^{\mathrm{c}}$ & $3.31^{\mathrm{a}}$ & $3.39^{\mathrm{a}}$ & $138.42^{\mathrm{bc}}$ & $177.17^{\mathrm{c}}$ & $8.75^{\mathrm{a}}$ & $5.85^{\mathrm{d}}$ & $3.58^{\mathrm{ab}}$ & $3.93^{\text {cd }}$ \\
\hline$\overline{1000 \mathrm{ppm}}$ & $12.93^{\mathrm{ab}}$ & $16.79^{\mathrm{a}}$ & $3.11^{\mathrm{a}}$ & $3.61^{\mathrm{a}}$ & $135.57^{\mathrm{c}}$ & $170.52^{\mathrm{d}}$ & $8.90^{\mathrm{a}}$ & $7.70^{\mathrm{bc}}$ & $3.45^{\mathrm{b}}$ & $4.13^{\mathrm{c}}$ \\
\hline $2000 \mathrm{ppm}$ & $12.27^{\mathrm{ab}}$ & $16.21^{\mathrm{a}}$ & $2.89^{\mathrm{a}}$ & $3.44^{\mathrm{a}}$ & $138.33^{\mathrm{cb}}$ & $185.17^{\mathrm{ab}}$ & $9.58^{\mathrm{a}}$ & $6.33^{\mathrm{d}}$ & $3.88^{\mathrm{a}}$ & $3.78^{\mathrm{cd}}$ \\
\hline $3000 \mathrm{ppm}$ & $13.50^{\mathrm{ab}}$ & $15.84^{\mathrm{ab}}$ & $3.37^{\mathrm{a}}$ & $3.96^{\mathrm{a}}$ & $140.70^{\mathrm{b}}$ & $182.84^{\text {bc }}$ & $8.65^{\mathrm{a}}$ & $8.31^{\mathrm{ab}}$ & $3.50^{\mathrm{ab}}$ & $5.10^{\mathrm{a}}$ \\
\hline $4000 \mathrm{ppm}$ & $12.32^{\mathrm{ab}}$ & $14.57^{\mathrm{bc}}$ & $3.19^{\mathrm{a}}$ & $3.75^{\mathrm{a}}$ & $138.49^{\mathrm{b}}$ & $181.89^{\mathrm{b}}$ & $9.28^{\mathrm{a}}$ & $8.48^{\mathrm{a}}$ & $3.25^{\mathrm{b}}$ & $4.63^{\mathrm{b}}$ \\
\hline $5000 \mathrm{ppm}$ & $10.64^{b}$ & $9.53^{\mathrm{d}}$ & $2.64^{\mathrm{a}}$ & $3.42^{\mathrm{a}}$ & $144.90^{\mathrm{a}}$ & $192.68^{\mathrm{a}}$ & $9.12^{\mathrm{a}}$ & $7.35^{\mathrm{c}}$ & $3.23^{\mathrm{b}}$ & $3.66^{\mathrm{d}}$ \\
\hline \multicolumn{11}{|l|}{ Interactions } \\
\hline Control & $17.47^{\mathrm{a}}$ & $16.69^{\mathrm{bc}}$ & $3.44^{\mathrm{a}}$ & $3.68^{\mathrm{a}}$ & $138.93^{\mathrm{bc}}$ & $176.33^{\mathrm{de}}$ & $7.57^{\mathrm{a}}$ & $4.66^{\mathrm{f}}$ & $3.74^{\mathrm{a}-\mathrm{d}}$ & $3.69^{\mathrm{c}}$ \\
\hline$\overline{\mathrm{SA}+1000 \mathrm{ppm}}$ & $15.04^{\mathrm{a}}$ & $21.98^{\mathrm{a}}$ & $2.94^{\mathrm{a}}$ & $4.61^{\mathrm{a}}$ & $136.20^{\mathrm{cd}}$ & $173.05^{\mathrm{e}}$ & $8.77^{\mathrm{a}}$ & $7.36^{\mathrm{bc}}$ & $4.12^{\mathrm{a}}$ & $4.14^{\mathrm{c}}$ \\
\hline $\mathrm{SA}+2000 \mathrm{ppm}$ & $13.11^{\mathrm{a}}$ & $17.34^{\mathrm{b}}$ & $2.53^{\mathrm{a}}$ & $3.91^{\mathrm{a}}$ & $139.17^{\mathrm{bc}}$ & $184.11^{\text {bed }}$ & $9.23^{\mathrm{a}}$ & $6.02^{\mathrm{de}}$ & $3.88^{\mathrm{abc}}$ & $3.79^{\mathrm{c}}$ \\
\hline $\mathrm{SA}+3000 \mathrm{ppm}$ & $14.29^{\mathrm{a}}$ & $14.91^{\mathrm{c}}$ & $2.66^{\mathrm{a}}$ & $3.95^{\mathrm{a}}$ & $144.71^{\mathrm{a}}$ & $191.01^{\mathrm{ab}}$ & $8.93^{\mathrm{a}}$ & $7.31^{\mathrm{bc}}$ & $3.72^{\mathrm{a}-\mathrm{d}}$ & $4.16^{\mathrm{c}}$ \\
\hline $\mathrm{SA}+4000 \mathrm{ppm}$ & $9.31^{\mathrm{a}}$ & $16.41^{\mathrm{bc}}$ & $2.13^{\mathrm{a}}$ & $3.86^{\mathrm{a}}$ & $145.37^{\mathrm{a}}$ & $190.68^{\mathrm{ab}}$ & $8.10^{\mathrm{a}}$ & $6.67^{\mathrm{cd}}$ & $3.75^{\mathrm{a}-\mathrm{d}}$ & $4.97^{\mathrm{b}}$ \\
\hline $\mathrm{SA}+5000 \mathrm{ppm}$ & $8.40^{\mathrm{a}}$ & $11.69^{\mathrm{de}}$ & $2.21^{\mathrm{a}}$ & $2.91^{\mathrm{a}}$ & $146.87^{\mathrm{a}}$ & $194.33^{\mathrm{a}}$ & $9.47^{\mathrm{a}}$ & $9.30^{\mathrm{a}}$ & $3.32^{\text {cde }}$ & $3.02^{\mathrm{d}}$ \\
\hline Control & $13.52^{\mathrm{a}}$ & $10.77^{\mathrm{e}}$ & $3.19^{\mathrm{a}}$ & $3.09^{\mathrm{a}}$ & $137.90^{c}$ & $178.00^{\text {cde }}$ & $9.93^{\mathrm{a}}$ & $7.05^{\text {bcd }}$ & $3.41^{\text {b-e }}$ & $4.16^{\mathrm{c}}$ \\
\hline$\overline{\mathrm{DES}+1000 \mathrm{ppm}}$ & $10.83^{\mathrm{a}}$ & $11.61^{\mathrm{de}}$ & $3.27^{\mathrm{a}}$ & $2.61^{\mathrm{a}}$ & $134.93^{\text {cd }}$ & $168.03^{\mathrm{e}}$ & $9.03^{\mathrm{a}}$ & $8.04^{\mathrm{b}}$ & $3.03^{\mathrm{e}}$ & $4.12^{\mathrm{c}}$ \\
\hline$\overline{\mathrm{DES}}+2000 \mathrm{ppm}$ & $11.42^{\mathrm{a}}$ & $15.07^{\mathrm{c}}$ & $3.24^{\mathrm{a}}$ & $2.97^{\mathrm{a}}$ & $137.51^{\mathrm{c}}$ & $186.33^{\mathrm{abc}}$ & $9.93^{\mathrm{a}}$ & $6.65^{\mathrm{cd}}$ & $4.03^{\mathrm{ab}}$ & $3.77^{\mathrm{c}}$ \\
\hline DES+3000 ppm & $12.72^{\mathrm{a}}$ & $16.15^{\mathrm{bc}}$ & $4.09^{\mathrm{a}}$ & $3.98^{\mathrm{a}}$ & $136.72^{\mathrm{c}}$ & $174.67^{\mathrm{de}}$ & $8.37^{\mathrm{a}}$ & $9.32^{\mathrm{a}}$ & $2.89^{\mathrm{e}}$ & $6.04^{\mathrm{a}}$ \\
\hline$\overline{\mathrm{DES}+4000 \mathrm{ppm}}$ & $15.33^{\mathrm{a}}$ & $12.72^{\mathrm{d}}$ & $4.27^{\mathrm{a}}$ & $3.65^{\mathrm{a}}$ & $131.60^{\mathrm{d}}$ & $173.11^{\mathrm{e}}$ & $10.47^{\mathrm{a}}$ & $10.29^{\mathrm{a}}$ & $2.75^{\mathrm{e}}$ & $4.29^{\mathrm{c}}$ \\
\hline$\overline{\mathrm{DES}}+5000 \mathrm{ppm}$ & $12.88^{\mathrm{a}}$ & $7.37^{\mathrm{f}}$ & $3.06^{\mathrm{a}}$ & $3.93^{\mathrm{a}}$ & $142.93^{\mathrm{ab}}$ & $191.04^{\mathrm{ab}}$ & $8.77^{\mathrm{a}}$ & $5.39^{\mathrm{ef}}$ & $3.13^{\mathrm{de}}$ & $4.30^{\mathrm{c}}$ \\
\hline
\end{tabular}

Values in each column followed by different superscript letter(s) are significantly different at $\mathrm{P} \leq 0.05$. $\mathrm{SA}=$ sodium azide; DES = diethyl sulfate.

\section{Flower yield components}

Data in Table 2 indicated that the chemical mutagen, mutagen concentration, and their interactions had significant effects on flowering date in both the $\mathrm{M}_{1}$ - and $\mathrm{M}_{2}$-generations. The DES mutagen resulted in an earlier flowering date for $\mathrm{M}_{1}$ - and $\mathrm{M}_{2}$-generations, compared with SA. The earliest flowering dates were detected at $1000 \mathrm{ppm}$ (135.57 days) for the $\mathrm{M}_{1}$ - and (170.52 days) $\mathrm{M}_{2}$-generations, whereas the latest date was attained at $5000 \mathrm{ppm}$ (144.90 and 192.68 days in the $M_{1}-$ and $M_{2}$-generations, respectively). The interaction effect with SA at $5000 \mathrm{ppm}$ delayed the flowering date of both $\mathrm{M}_{1}$ - and $\mathrm{M}_{2}$-generation calendula plants (146.87 and 194.33 days) comparing to other treatments.

The number of inflorescences per plant was not affected by either SA or DES; especially in the $\mathrm{M}_{1}$-generation (Table 2). However, the two chemical mutagens, mutagen concentration, and their interactions revealed significant influences in the $\mathrm{M}_{2}$-generation. DES had a superior effect on the number of inflorescences, comparing to SA. A higher mutagen concentration of $4000 \mathrm{ppm}$ appeared to result in a higher number of inflorescences (8.48), followed by 3000 ppm (8.31), and compared to the control (5.85) or other treatments. The effects of the DES mutagen at the higher concentration of $4000 \mathrm{ppm}$ gave the highest value of inflorescence number per plant (10.29) as compared to the control ones (4.66) or other treatments.

The data in Table 2 illustrate that the differences between the two chemical mutagens, mutagen concentration, and their interactions during both the $\mathrm{M}_{1}-$ and $\mathrm{M}_{2}-$ generations were significantly compared with the control treatment.

In the $\mathrm{M}_{1}-$ and $\mathrm{M}_{2}$-generations, the lowest mean inflorescence diameters were 
observed at the concentration of $5000 \mathrm{ppm}(3.23$ and $3.66 \mathrm{~cm})$, while the highest diameters were detected at $2000 \mathrm{ppm}(3.88 \mathrm{~cm})$ for the $\mathrm{M}_{1}$-generation and at $3000 \mathrm{ppm}(5.10 \mathrm{~cm})$ for the $\mathrm{M}_{2}$-generation. Data revealed that the interaction effect of SA at $1000 \mathrm{ppm}$ and DES at 3000 ppm generated the highest inflorescence diameter values $(4.12$ and $6.04 \mathrm{~cm}$ ), compared to all other treatments in the $\mathrm{M}_{1}$ - and $\mathrm{M}_{2}$-generations (Table 2).

\section{Gas-exchange measurements}

The data shown in Figure 1A-D illustrate that there were significant differences between the two chemical mutagens and their concentrations, compared with the control treatment in both generations. With the exception of stomatal conductance at $5000 \mathrm{ppm}$ DES, net photosynthetic rate, stomatal conductance, and transpiration rate all increased in the presence of DES at all concentrations, compared with SA. The intercellular $\mathrm{CO}_{2}$ concentration with SA was relatively more effective than with DES. In the $\mathrm{M}_{2}$-generation, an increase in all measurements was observed. Regarding the intercellular $\mathrm{CO}_{2}$ concentration, SA exposure resulted in a greater sensitivity to higher concentrations of mutagens. The intercellular $\mathrm{CO}_{2}$ concentration was higher in the SA than in the DES treatment. There was a trend towards an increase in intercellular $\mathrm{CO}_{2}$ concentration with increasing the chemical concentrations from 1000 to $5000 \mathrm{ppm}$.

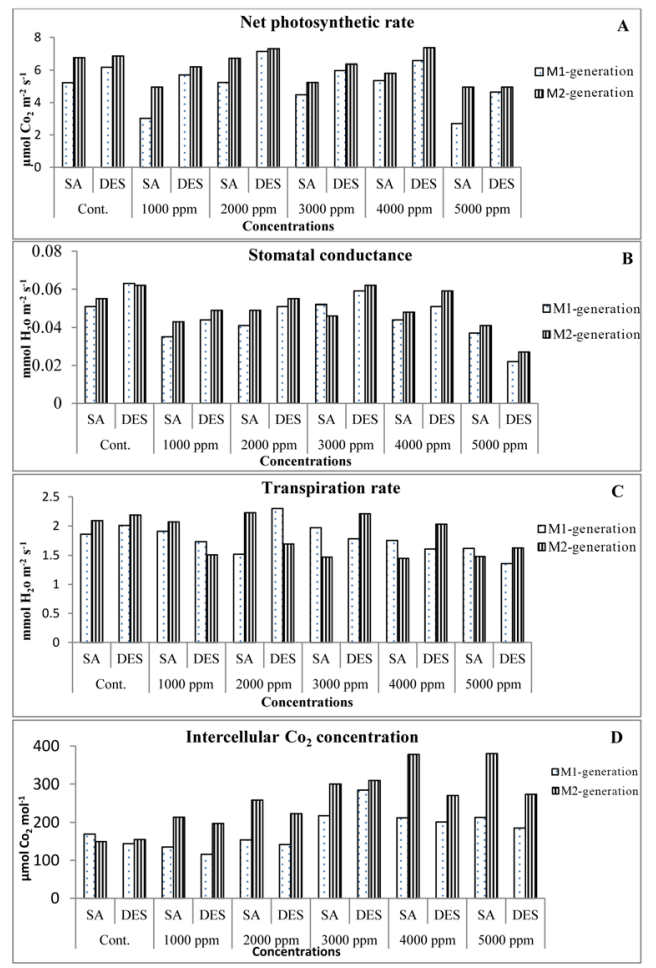

Figure 1. Net photosynthetic rate (A), stomatal conductance $(\mathbf{B})$, transpiration rate $(\mathbf{C})$, and intercellular $\mathrm{CO}_{2}(\mathbf{D})$ following exposure to two chemical mutagens (SA and DES) on calendula plants. The mutagens were applied at control, 1000, 2000, 3000, 4000, and $5000 \mathrm{ppm}$, during two generations $\left(\mathrm{M}_{1}\right.$ and $\left.\mathrm{M}_{2}\right)$. 


\section{Leaf chlorophyll contents}

The mean values of leaf $\mathrm{Chl}$ contents are presented in Figure 2A and B. There were significant effects in the $\mathrm{M}_{1}$-generation with respect to the chemical mutagen, mutagen concentration, and their interactions. However, in the $\mathrm{M}_{2}$-generation, there were no significant differences. The concentration of $5000 \mathrm{ppm}$ in the $\mathrm{M}_{1}^{2}$-generation significantly reduced the total Chl content $(2.05 \mu \mathrm{M})$, as compared with all other treatments. In the present study, the total Chl content in plants treated with DES increased at higher concentrations, whereas SAtreated plants had higher total $\mathrm{Chl}$ at the lower concentrations.
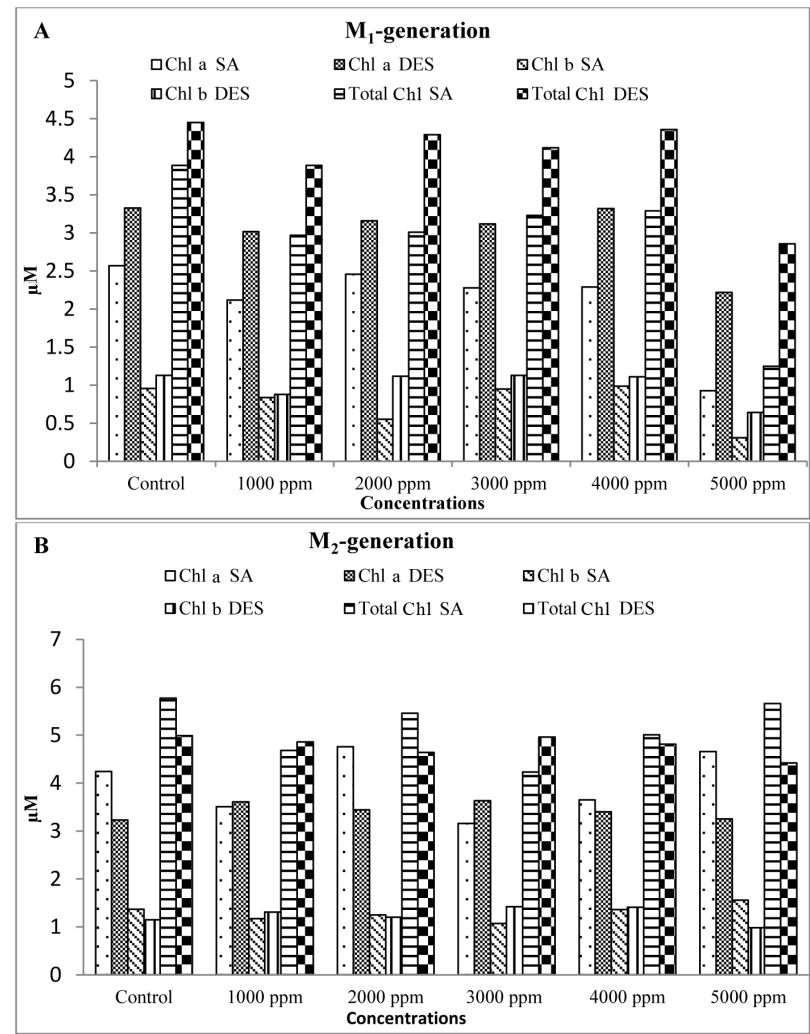

Figure 2. Chlorophyll (Chl) a, b, and total $\mathrm{Chl}$ concentrations in calendula plants following exposure to two chemical mutagens (SA and DES) at different concentrations over two generations, $\mathrm{M}_{1}(\mathbf{A})$ and $\mathrm{M}_{2}(\mathbf{B})$.

\section{Total soluble protein content}

Figure $3 \mathrm{~A}$ shows that the lowest total soluble protein was found in calendula plants that had been treated with $5000 \mathrm{ppm}$ SA and DES treatments (3.86 and $3.67 \mathrm{mg}$ protein/g tissue, respectively), whereas the highest total soluble protein was detected at the concentrations of $1000 \mathrm{ppm} \mathrm{SA} \mathrm{(4.76} \mathrm{mg} \mathrm{protein/g} \mathrm{tissues)} \mathrm{and} 2000 \mathrm{ppm}$ DES (4.45 mg protein/g tissues). In the comparison between the two mutagens, data indicated that SA had the highest average total soluble protein content, except for at $4000 \mathrm{ppm}$ DES. 


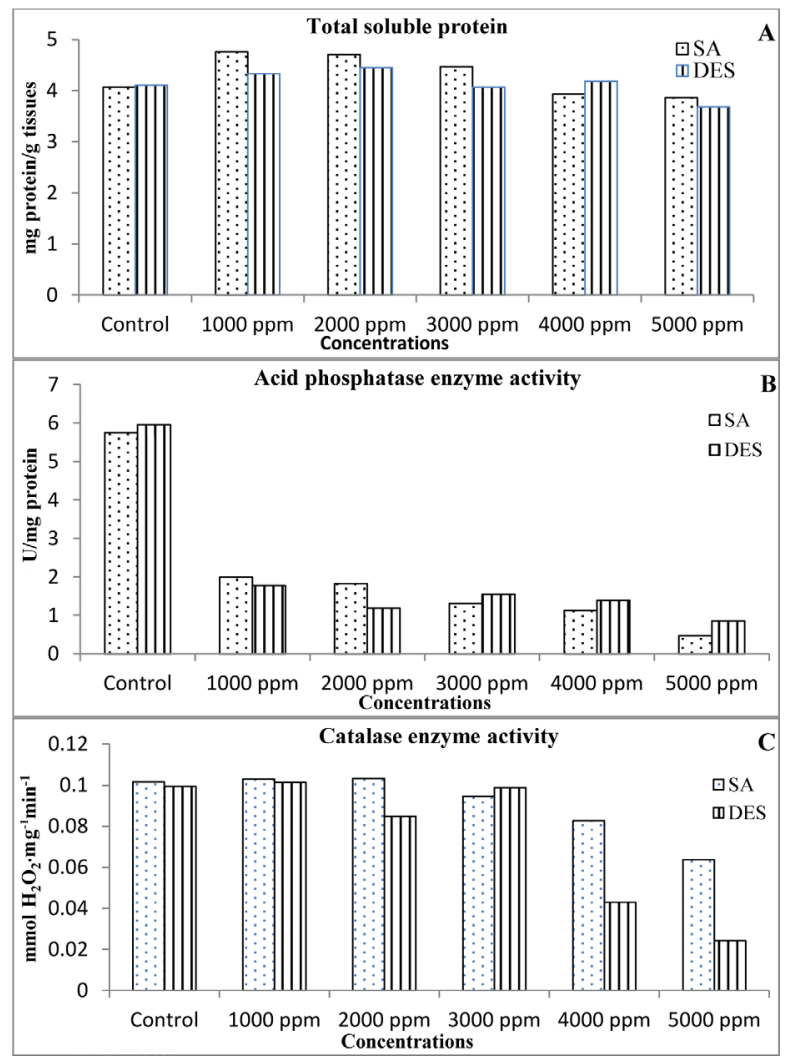

Figure 3. Total soluble protein (A), acid phosphatase enzyme activity (B), and catalase enzyme activity $(\mathbf{C})$ in calendula plants following exposure to chemical mutagens (SA and DES) at different concentrations during two generations $\left(\mathrm{M}_{1}\right.$ and $\left.\mathrm{M}_{2}\right)$.

\section{Enzyme activity}

Data presented in Figure 3B show that the control plants had the highest average acid phosphatase enzyme (SA: 5.75 and DES: $5.96 \mathrm{U} / \mathrm{mg}$ protein). The lowest mean of the enzyme was detected at the concentration of $5000 \mathrm{ppm} \mathrm{SA}(0.47 \mathrm{U} / \mathrm{mg}$ protein) and DES $(0.86 \mathrm{U} / \mathrm{mg}$ protein). The comparison between the two mutagens revealed that DES resulted in a higher average acid phosphatase activity than SA. However, the growth conditions also significantly affected the catalase activity of the leaves (Figure 3C). Plants collected from SA and DES had more catalase activity at lower mutagen concentrations. The minimum catalase activity was noticed in leaves of $5000 \mathrm{ppm}$ mutagen-treated plants.

\section{DISCUSSION}

There was a reduction in the germination percentage of calendula plants as the concentrations of the SA and DES mutagens in both the $\mathrm{M}_{1}$ - and $\mathrm{M}_{2}$-generation increased. Similar reductions in germination due to hydroxylamine mutagen have also been reported in cowpea species (Mensah and Akomeah, 1992). The changes that occurred in the germination 
percentage in seeds of $\mathrm{M}_{1}-$ and $\mathrm{M}_{2}-$ generations could be due to the environmental effects; such as, seed moisture contents as well as the mutagen chemical concentrations (Abd ElMaksoud and El-Mahrouk, 1992). These results are consistent with those found by Badr et al. (2000) and El-Nashar (2006) whose results indicated that mutagen stimulation affected the germination of Tagetes and Amaranthus seeds as a result of low concentrations of mutagenic chemicals. The stimulating effects of low and intermediate concentrations of SA and DES on seed germination may be due to enzymatic activation and awakening of meristematic cell division. Disturbance in the formation of enzymes involving in the germination process, particularly at higher doses, could be considered one of the physiological effects caused by SA and DES, which leads to a decreased germination percentage in calendula plants.

Plant height increased with the lower mutagen concentrations. This has also been observed in other floricultural species, such as Salvia splendens (Hussein et al., 1974), Euonymus japonicus (El-Torky, 1992), and Amaranthus (El-Nashar, 2006). The stimulatory effects of the lower concentrations on plant height also agreed with the findings of Abd ElMaksoud and El-Mahrouk (1992) on Asparagus densiflorus. These results might be attributed to the physiological damages caused by SA and DES and their hydrolysis products.

Clear significant effects on the number of branches and leaves per plant were also recorded. These results are in accordance with the findings of Hussein et al. (1974) on Salvia splendens and El-Nashar (2006) on Amaranthus. The physiological effects of SA, DES and their hydrolysis products could also be the reason for increasing the number of branches and leaves in each plant.

The proportional increases and decreases in the fresh and dry weights, respectively, with increasing SA and DES concentrations reported in this study, were similar to those findings of Abd El-Maksoud and El-Mahrouk (1992) on Asparagus densiflorus. The difference in responses at various doses could be attributed to the environmental factors, such as temperatures and/or nutrition that prevailed during the growth period of the plants.

Regarding flowering date, the two manners of responses to mutagens have been reported. Plants may be triggered to flower earlier, as reported by Hussein et al. (1974) who found that ethyl methanesulfonate concentrations resulted in a significant responses towards earliness of flowering in Salvia splendens, maize (Afsar-Awan et al., 1980; Lysikov et al., 1987), and winter Swede rape (Adamska et al., 1995). The alternative response is pushing plants towards a later flowering date as was reported by El-Nashar (2006) who found that DES concentrations caused a slight delay in flowering of Amaranthus and Mahna et al. (1990) showed similar results in Vinga aconitifolia. The variable responses observed in the present study could be due to the environmental variations between the two seasons. It is known that low and intermediate concentrations of mutagens generally stimulate cell growth, increase growth rate, and produce earlier flowering in specific cases as reported by Hussein et al. (1974) and Adamska et al. (1995). On the other hand, elevated concentrations seemed to inhibit the cell growth, decrease growth rate, and delay the flowering date, as reported by Neagu (1970), Khan et al. (1994), Badr et al. (2000), and El-Nashar (2006).

The inflorescence diameters found in the present study were in contrast with those reported by Mahna and Singh (1975) on Physalis ixocarpa plant and on Amaranthus by ElNashar (2006). The environmental and physiological conditions at the middle of the flowering period can affect the inflorescence quality. When the growth reached its maximum, the photoperiod was longer. Therefore, the diameters of the inflorescences and leaf area increased as a result of light intensity and higher temperatures. 
Kumar et al. (1994) showed that net photosynthetic rate, transpiration rate, and dry mass production were closely related processes. Both photosynthetic and transpiration rate are regulated by the stomatal activity (Nguyen et al., 1997), and both have been found to be highly correlated in cassava plants (Mahon et al., 1977). Decreases in net photosynthetic rate closely follow decreases in transpiration rate, since stomatal closure controls both processes (Ike, 1982). This indicates that the low transpiration rate of calendula plants was reduced in the $M_{1}$ generation, as a result of decreasing photosynthesis. The stomatal conductance found in the present study was in full agreement with that of Lahai and Ekanayake (2010) who reported that stomatal apertures of the high-yielding cultivars with intermediate rate of transpiration were open wide enough to allow high photosynthesis, but restricted enough to prevent excessive loss of water from leaves, resulting in a high leaf yield.

Soaking seeds in SA and DES treatments produced mutations with reduced chlorophyll content that were more pronounced in the $\mathrm{M}_{1}$-generation. This was in accordance with the findings of Cneng and Gao (1988). There might be two reasons for this; the first one is that the post-SA soaking may cause diffusion of SA molecules from cells to the extra-cellular fluid, or an inactivation of SA by cellular fluids, resulting in a reduction of the "active" concentration. The second reason could be that repairing of the SA-inducing lesions may take place during the post-SA soaking period.

The changes in soluble protein patterns were obvious at all experimental conditions used in this study. It must be emphasized that reduction in protein could be as a result of the direct physical effects of the chemical mutations on molecules, and protein increases may reflect the repression of gene expression as suggested by Gorinstein et al. (2001) and del Carmen Ramírez-Medeles et al. (2003) on Amaranthus species.

A drastic decrease in the acid phosphatase enzyme activity was detected. The results can be attributed to the cellular response to mutagens as reported by dos Prazeres et al. (2004). Vaidyanathan et al. (2003) mentioned that catalase enzyme is used to decrease oxidants like $\mathrm{H}_{2} \mathrm{O}_{2}$. In the present study, more catalase activity was observed under the low mutagen concentrations. A contrasting response in catalase activity to different chemical mutagen stresses has been shown in previous studies. Wildeman and Nazar (1982) found no correlation between activation levels in various plant species, their protein contents, and catalase activities.

\section{CONCLUSION}

Chemical mutagenesis is an efficient tool used in mutation-breeding programs to improve the vital characters of the floricultural crops. This study was aimed to estimate the effect of different concentrations of two chemical mutagens; sodium azide and diethyl sulfate. Lower concentrations of mutagens were found to be beneficial for seed germination percentage, plant height, leaf area, fresh plant weight, flowering date, inflorescence diameter, and gas-exchange of calendula plants, in both generations. The chemical mutagens and mutagen concentrations had significant effects on total soluble proteins, acid phosphatase, and catalase activity fractions of the calendula leaves.

\section{Conflicts of interest}

The authors declare no conflict of interest. 


\section{ACKNOWLEDGMENTS}

The authors would like to extend their sincere appreciations to the Deanship of Scientific Research, King Saud University, Saudi Arabia, for funding this studing through the Research Group Project \#RGP-270.

\section{REFERENCES}

Abd El-Maksoud B and El-Mahrouk EM (1992). Effect of ethyl methane sulfonate on the growth and interior quality of Asparagus densiflorus (Kunth) Jessop C.V. "SPRENGERI. Egypt. J. Appl. Sci. 7: 116-132.

Adamska E, Jezowski S, Olejniczak J and Rybinski W (1995). Effect of chemical mutagens on induced variation in winter Swede rape. Rośliny Oleiste XVI: 57-62.

Afsar-Awan M, Konzac CF, Rutger JN and Nilan RA (1980). Mutagenic effects of sodium azide in rice. Crop Sci. 20: 663-668.

Badr M, El-Torky MG, El-Shennawy O and El-Nashar Y (2000). Effect of chemical mutagens on Tagetes erecta. J. Agr. Sci. Mansoura Univ. 25: 5241-5256.

Cakmak I, Strbac D and Marschner H (1993). Activities of hydrogen peroxide-scavenging enzymes in germinating wheat seeds. J. Exp. Bot. 44: 127-132. http://dx.doi.org/10.1093/jxb/44.1.127

Chopra VL (2005). Mutagenesis Investigating the process and processing the outcome for crop improvement. Curr. Sci. 89: 353-359.

Cneng XY and Gao MW (1988). Biological and genetic effects of combined treatments of sodium azide, gamma rays and EMS in barley. Environ. Exp. Bot. 28: 281-288. http://dx.doi.org/10.1016/0098-8472(88)90051-2

del Carmen Ramírez-Medeles M, Aguilar MB, Miguel RN, Bolaños-García VMB, et al. (2003). Amino acid sequence, biochemical characterization, and comparative modeling of a nonspecific lipid transfer protein from Amaranthus hypochondriacus. Arch. Biochem. Biophys. 415: 24-33. http://dx.doi.org/10.1016/S0003-9861(03)00201-7

dos Prazeres JN, Ferreira CV and Aoyama H (2004). Acid phosphatase activities during the germination of Glycine max seeds. Plant Physiol. Biochem. 42: 15-20. http://dx.doi.org/10.1016/j.plaphy.2003.10.009

El-Nashar Y (2006). Effect of chemical mutagens (sodium azide and diethyl sulphate) on growth, flowering and induced variability in Amaranthus caudatus L. and A. hypochondriacus L. Doctoral thesis, Faculty of Agriculture Alexandria University.

El-Torky MG (1992). Effect of EMS (ethylmethan sulphonate) on variegation type and some other horticultural traits in Euonymus japonicus, Linn. Alex. Agric. Res. 37: 249-260.

Gaul H (1964). Mutation in plant breeding. Radiat. Bot. 4: 155-232. http://dx.doi.org/10.1016/S0033-7560(64)80069-7

Gorinstein S, Delgado-Licon E, Pawelzik E, Permady HH, et al. (2001). Characterization of soluble amaranth and soybean proteins based on fluorescence, hydrophobicity, electrophoresis, amino Acid analysis, circular dichroism, and differential scanning calorimetry measurements. J. Agric. Food Chem. 49: 5595-5601. http://dx.doi.org/10.1021/ jf010627g

Hussein HAS, Sallam SH, Kamel HA and Labib T (1974). The mutagenic effects of EMS on Salvia splendens. Egypt. J. Genet. Cytol. 3: 193-203.

Ike IF (1982). Effect of water deficits on transpiration, photosynthesis and leaf conductance in cassava. Physiol. Plant. 55: 411-414. http://dx.doi.org/10.1111/j.1399-3054.1982.tb04520.x

Khan S, Siddiqui BA and Nadeem M (1994). Variation in quantitative characters of mungbean after seed treatment with dES. Adv. Plant Sci. 7: 41-45.

Khan S, Al-Qurainy F and Anwar F (2009). Sodium azide: A chemical mutagen for enhancement of agronomic traits of crop plants. Environ. We Int. J. Sci. Tech. 4: 1-21.

Kumar A, Singh DP and Singh P (1994). Influence of water stress on photosynthesis, transpiration, water-use efficiency and yield of Brassica juncea L. Field Crops Res. 37: 95-101. http://dx.doi.org/10.1016/0378-4290(94)90037-X

Lahai MT and Ekanayake IJ (2010). Transpiration rate and leaf water potential as indices for cassava yield in inland valley ecology. J. Agric. Sci. Technol.; JAST 4: 34-44.

Lowry OH, Rosebrough NJ, Farr AL and Randall RJ (1951). Protein measurement with the Folin phenol reagent. J. Biol. Chem. 193: 265-275.

Lysikov VN, Mordvinova VG and Stoilov M (1987). Effect of ecological conditions on genotypic variation in maize mutants under the influence of chemical mutagens. Plant Bree. Gen 58: 88-91.

Mahna SK and Singh D (1975). Induced floral mutation in Physalis ixocarpa Brot. Curr. Sci. 44: 21-22. 
Mahna SK, Bhargva A and Mohan L (1990). Alkaline azide mutagenic in cowpea. FAO/IAEA Div. Nucl. Tech. Food Agr. Vienna 32: 6-7.

Mahon JD, Lowe SB and Hunt LA (1977). Variation in rate of photosynthetic $\mathrm{CO}_{2}$ uptake in cassava and selected species of Manihot. Photosynthetica 11: 131-138.

Mensah JK and Akomeah PA (1992). Mutagenic effect of hydroxylamine and streptomycin on the growth and yield of cowpea Vigna unguiculata (L.) Walp. Legume Res. 15: 39-44.

Mensah JK and Obadoni O (2007). Effects of sodium azide on yield parameters of groundnut (Arachis hypogea L.). Afr. J. Biotechnol. 6: 20-25.

Mostafa GG (2011). Effect of sodium azide on the growth and variability induction in Helianthus annuus L. Int. J. Plant Breed. Genet. 5: 76-85. http://dx.doi.org/10.3923/ijpbg.2011.76.85

Neagu M (1970). Contributions on the mutagenic effect of diethyl sulphate on sunflower (Helianthus annuиs L.). Lucrari Stiintifice, Institutul Agronomic Timisoara. Agronomie 13: 537-548.

Nguyen HT, Babu RC and Blum A (1997). Breeding for drought resistance in rice: Physiology and molecular genetics considerations. Crop Sci. Soc. Am. 37: 1426-1434. http://dx.doi.org/10.2135/cropsci1997.0011183X003700050002x

Porra RJ, Thompson WA and Kriedemann PE (1989). Determination of accurate extinction coefficients and simultaneous equations for assaying chlorophylls $a$ and $b$ extracted with four different solvents: verification of the concentration of chlorophyll standards by atomic absorption spectroscopy. Biochim. Biophys. Acta 975: 384-394. http://dx.doi. org/10.1016/S0005-2728(89)80347-0

Roychowdhury R and Tah J (2011). Chemical mutagenic action on seed germination and related agro-metrical traits in M1 Dianthus generation. Curr. Bot. 2: 19-23.

Roychowdhury R, Datta S, Gupta P and Tah J (2012). Analysis of genetic parameters on mutant populations of Mungbean (Vigna radiata L.) after ethyl methane sulphonate treatment. Not. Sci. Biol. 4: 137-143.

Singh J and Singh S (2001). Induced mutations in basmati rice (Oryza sativa L.). Diamond Jub. Symp, New Delhi, 212.

Sinhamahapatra SP and Rakshit SC (1990). Response to selection for plant height in X-ray treated population of jute (Corchorus caspularis L.) cv. JRC 212. Euphytica 51: 95-99.

Steel RGD and Torrie JH (1980). Principles and procedures of statistics: A biometrical approach. 2nd edn. McGraw-Hill, New York.

Tah PR (2006). Induced macromutation in mungbean. Intl. J. Bot. 2: 219-228. http://dx.doi.org/10.3923/ijb.2006.219.228

Vaidyanathan H, Sivakumar P, Chakrabarsty R and Thomas G (2003). Scavenging of reactive oxygen species in NaClstressed rice (Oryza sativa L.)-differential response in salt-tolerant and sensitive varieties. Plant Sci. 165: 1411-1418. http://dx.doi.org/10.1016/j.plantsci.2003.08.005

Wildeman AG and Nazar RN (1982). Significance of plant metabolism in the mutagenicity and toxicity of pesticides. Can. J. Genet. Cytol. 24: 437-449.http://dx.doi.org/10.1139/g82-046 